\title{
Comparing Two Program Contents with IT2005 Body of Knowledge
}

\author{
Azad Ali \\ Indiana University of Pennsylvania \\ Indiana, PA, USA
}

\author{
azad.ali@iup.edu
}

\author{
Frederick Kohun \\ Robert Morris University, \\ Pittsburgh, PA, USA
}

kohun@rmu.edu

\begin{abstract}
Academic computing programs often want to keep pace with technological changes by frequently updating their program contents. These program changes are often reactionary and lack uniform standards. Thus some of the changes are often rolled back and, as a result, face additional changes shortly after their implementation. A helpful strategy in computer program updates is to utilize a standard curriculum to gauge and benchmark the program.

This paper compares the content of two technology programs with a standard curriculum developed by the Association of Computing Machinery (ACM) and other organizations including, AIS, AITP, IEEE and ABET-CAC. The paper examines the content of two technology programs: The Technology Support and T raining program (T ST) at Eberly College of Business - Indiana University of Pennsylvania (IUP), and the Computer Information Systems (CIS) and Information Sciences (IS) programs in the School of Communications and Information Technology at Robert Morris University (RMU). It then compares the content of both programs with the Computing Curricula Information - Information Technology Volume (IT2005) Body of Knowledge.
\end{abstract}

Keywords: Comparing two computer programs with IT2005, Computer programs and standard curriculum, Computer programs, technology curriculum IT2005, AIS, AITP, and ABET-CAC

\section{Introduction}

This paper builds on a previously published paper by the same authors. In the first paper Ali, Kohun, and Wood (2007) compared two program contents with Comput ing Curriculum 2005 (CC2005) knowledge area. The previous study concluded that both programs are retrospectively aligned with the Information Technology list of the knowledge areas in CC2005. After publication of the first paper, the authors learned of the development of a new volume of standard curriculum called "Information Technology Volume Body of Knowledge" or IT2005. Building on the conclusion that the two programs are closely aligned with IT2005, the authors decided to

\footnotetext{
Material published as part of this publication, either on-line or in print, is copyrighted by the Informing Science Institute. Permission to make digital or paper copy of part or all of these works for personal or classroom use is granted without fee provided that the copies are not made or distributed for profit or commercial advantage AND that copies 1 ) bear this notice in full and 2) give the full citation on the first page. It is permissible to abstract these works so long as credit is given. To copy in all other cases or to republish or to post on a serveror to redistribute to lists requires specific permission and payment of a fee. Contact Publisher@ InformingScience.org to request redistribution permission.
}

pursue this issue further and see how different the programs may actually be, yet still remain in compliance with the IT 2005 model curriculum.

Computer technology programs are numerous. Their program names and their scope of coverage may differ vastly. The same thing can be said about computer courses; they vary, their names are different and their content could overlap 
from one course to another. In cases when updating computer program curriculum, designers are faced with difficult choices among course and program names as well as content. In these cases, consulting standard curriculum helps in identifying the disposition of the program and in identifying the steps needed to be in compliance with the standard program.

In this paper the content of two programs are compared with the IT2005 standard curriculum. The two programs with the compared content are the TST program at IUP and the CIS program at RMU. The intention of the paper is to find the common courses between these two programs and the IT2005 suggested body of knowledge and then determine what is missing from the programs and to determine if there is any overlap or over-coverage.

The remainder of the paper is divided into four sections. The first section offers a brief history of the computing curriculum. The second section explains in more details about the IT 2005 as well as the development and the content of this standard curriculum. The third section explains the two programs - the TST program at IUP and the CIS program at RMU. Finally, the fourth section makes the comparison between IT2005 and the two programs being discussed here. At the end of the paper a conclusion and suggestion for future research is presented.

\section{Computing Curriculum - A Brief History}

The attempts to develop standard computing curriculums have been going on for a number of years. These attempts at standards development has been evolving in a number of areas of technology as well as the number of new topics included in each technology area. The ways in which the standard curriculum is evolving parallels the increase in the use of technology in education as well as in business and government.

There are a number of organizations that work to develop standards for various technology fields: The Association for Computing Machinery (ACM), the Institute for Electronic, Engineering and Electric (IEEE), the Association of Information Systems (AIS) and the Association of Information Technology Professionals (AITP). These organizat ions have worked at many levels to develop standard curriculum for different computer disciplines. They have developed a number of documents in this regard and have indicated that they will continue to do so to develop additional documents ad the need for developing such documents arises. The initial focus of these efforts was to develop a standard curriculum for the computer science majors. This evolved into a larger number of standard curriculums to cover wider range of computer related programs.

The documents that are developed by these organizations are labeled as computing curriculum, though not officially considered "standards", they have been widely used in curriculum development and accredit ation (Dark, Ekstrom, \& Lunt, 2006). In fact, due to their wide use in higher education, these documents are considered as de facto standard curriculum in the comput ing technology fields.

Developing the initial standard curriculum in the computer field dates back to 1968 when the first computer curriculum was published for computer science (CS) by the ACM (Hart, 2006). Since that time, the ACM curriculum was followed by a series of curriculum standards that included the latest technology fields, such as the information systems volume (IS97 and IS2002), the soft ware engineering (SE2004), and computer engineering (CE2004) (Reynolds, 2006). All these volumes were specific to one computer field and none crossed more than onetechnology field. At one point, the computing curriculum was limited mainly to three programs: Computer Science, Information Systems and Computer Engineering. The Computer Engineering program was often taught within the college of Electrical Engineering and Information Technology was not yet considered a separate field of technology. 
The turn of the new century witnessed an increase in the number of programs that teaches computertechnology with all it variation and breadth. New programs were formed with the increased use of web technology. As a result of this technology curricular explosion, curriculum designers thought that it may be necessary to design a standard curriculum that spans across multiple fields. Therefore the Computing Curriculum 2005 (or CC2005) standard document was developed. The development of CC2005 served two purposes: First, it identified the fields or the academic programs that are supposed to be computer technology programs; and second, it listed specific fields that are included under each domain (Hart, 2006).

CC2005 identified five computer related programs: Computer Science (CS), Information Systems (IS), Information Technology (IT), Computer Engineering (CE) and Soft ware Engineering (SE). Along with a list of the five technology fields, CC2005 provided a scoring mechanism for the coverage (or domain) area for five technology fields. Although there is some overlap in the coverage area among these five fields, CC2005 provided ample description of each of the coverage areas for the five technology fields. CC2005 explained the main purpose and the foundation of this report:

"The foundation of this report is the set of standards that exist for undergraduate degree programs in five major computing-related field .... Each of the specific curricula volumes represents the best judgment of the relevant professional, scientific, and educational association and serves as a definition of what these degrees should be" (p.4).

\section{About IT2005}

Up until the development of CC2005, there were volumes of st andard curriculum for each of the five areas listed in CC2005 except the information technology volume. IT, as discipline, was not widely recognized as a separate discipline. Instead, the content of IT curriculum was taught within the context of different technology programs. However, the changes in technology and its wide spread use led to the evolution of a new field of technology that is different, in many areas, from the previously established fields. This new technology field is called the Information Technology (Or IT) field. CC2005 listed the following about IT programs:

"IT programs exist to produce graduates who possess the right combination of knowledge and practical, hands-on expertise to take care of both an organization's information technology infrastructure and the people who use it. IT specialist s assume responsibility for selecting hardware and soft ware products appropriate for an organization, integrating those products with organizational needs and infrastructure, and installing, customizing, and maint aining those applications for the organization's computer users" (p. 19).

The diversity of the computer applications and the wide area it covers led academics to think about starting a new program that is different from existing ones. This new program was intended to cover the wider range organizational need that was not covered under the previously developed documents. Thus IT began to gain a foothold in academia as a separate discipline. As a result, a new volume of standard comput ing curriculum was developed under the name of "Computing Curriculum Information Technology Volume" or IT2005.

The remainder of this section provides more explanation about the IT field in terms of definition, the skills it requires, the intended outcome and other information 


\section{IT as an Academic Discipline}

As noted earlier, the new document "Computing Technology Information Technology Volume" was introduced as a result of expansion of the IT discipline. At the beginning of the IT2005 document, there is a broad definition of the IT discipline:

"IT, as an academic discipline, focuses on meeting the needs of users within on organizational and societal context through the selection, creation, application, integration and administration of computing technologies".

\section{IT Skills}

The IT2005 identified the skills and knowledge areas that graduates of the IT discipline must have. IT2005 lists goals and expected outcomes that graduates of the discipline must have upon graduation. Specifically, IT2005 noted that within five years of graduation an IT graduate must be able to:

1. Explain and apply appropriate information technologies and employ appropriate methodologies to help an individual or organization achieve it s goals and objectives;

2. Manage the information technology resources of an individual or organization;

3. Anticipate the changing direction of information technology and evaluate and communicate the likely utility of new technologies to an individual or organization;

4. Understand and for some to contribute to the scientific, mathematical and theoretical foundations on which information technologies are built;

5. Live and work as a contributing, well-rounded member of society.

\section{IT Program Outcomes}

The IT2005 went a step further in identifying program outcomes. These outcomes are intended to enable IT graduates to achieve the goals listed above. Thus, according to this standard curriculum, IT students must possess the following skills upon graduation, namely the ability to:

a) Use and apply current technical concepts and practices in the core information technologies;

b) Analyze, identify and define the requirements that must be satisfied to address problems or opport unities faced by organizations or individuals;

c) (c) Design effective and usable IT-based solutions and integrate them into the user environment

d) Assist in the creation of an effective project plan;

e) Identify and evaluate current and emerging technologies and assess their applicability to address the users' needs;

f) Analyze the impact of technology on individuals, organizations and society, including ethical, legal and policy issues;

g) Demonstrate an understanding of best practices and standards and their application;

h) Demonstrate independent critical thinking and problem solving skills;

i) Collaborate in teams to accomplish a common goal by integrat ing personal initiative and group cooperation. 
j) Communicate effectively and efficiently with clients, users and peers both verbally and in writing, using appropriate terminology;

k) Recognize the need for continued learning throughout their career

\section{Body of Knowledge}

One of the first steps that IT 2005 has taken in order to develop a curriculum for the Information Technology discipline is to identify the material and coverage area that is appropriate for the discipline. In defining a curriculum for the IT discipline, IT2005 identified twelve set of knowledge areas. Within each knowledge area, the same document suggests a number of units to be covered and also the suggested number of hours required for each knowledge area. In order to provide context for the coverage area of IT2005 document, the following is a list of the 12 coverage area suggested by IT 2005 :

ITF Information Technology Fundamentals

HCI Human Computer Interaction

IAS Information Assurance and Security

IM Information Management

IPT Integrative Programming \& Technologies

NET Networking

PF Programming Fundamentals

PT Platform Technologies

SA Sy stems Administration and Maintenance

SIA Sy stem Integration \& Architecture

SP Social and Professional Issues

WS Web Systems and Technologies

\section{IT2005 Pervasive Themes}

In order to set graduates of the IT discipline apart from other fields in computing technology, IT 2005 defined that:

The curriculum must reflect those aspects that set Information Technology apart from other computing disciplines. The integration of different technologies and the integration of technologies into organizations are fundamental to Information Technology. An IT graduate must therefore acquire a skill set that enables him or her to successfully perform integrative tasks, including user advocacy skills, the ability to address information assurance and security concerns, the ability to manage complexity through abstraction, a deep understanding of the technology, adaptability, outstanding interpersonal skills, high ethical standards, and professional responsibility (P. 11)

Further, IT2005 developed a set of "pervasive themes" that identify the boundaries of their coverage areas. The pervasive themes of IT 2005 are listed below:

- User centeredness and advocacy

- Information assurance and security

- Ethics and professional responsibility

- The ability to manage complexity through: abstraction \& modeling, best practices, patterns, standards, and the use of appropriate tools

- A deep understanding of information and communication technologies and their associ- 
ated tools

- Adaptability

- Professionalism (life-long learning, professional development, ethics, responsibility)

- Interpersonal skills

\section{The Two Programs}

This section describes the two technology programs that were mentioned earlier in the paper:The TST program at IUP and the CIS/IS programs at RMU. In order to provide a framework for comparing these two programs with IT2005, the section provide broad explanation of the program first, then it lists the definition and the course units offered in each program. For each program, the section starts by giving a brief description of the purpose of the program and then list goals and objectives of the programs so to be able to set the stage to compare the programs at a later section of this paper.

\section{The TST Program at IUP}

The Technology Support and Training (TST) department in the Eberly College of Business and Information Technology (ECOBIT) at Indiana University of Pennsylvania (IUP) offer two bachelor degrees and one associate degree. The first Bachelor of Science degree is in Business Technology Support while the second is in Business Education. The Associate degree is in Computer and Information Technology.

The TST department is one of three departments at IUP that offers a computer technology related degree. The other two are Computer Science (CS) and Management Information Systems (MIS). There are other departments that teach some components of technology such as Communication Media and Marketing. But in general, the three departments of CS, MIS, and T ST offer degrees specifically in the computer related field.

The program has a mission statement which broadly defines the purpose of the program and the intended outcome. It also has list of program objectives and intended outcome. These compares to the IT2005 expected outcome listed earlier in this paper. Besides, the program has a number of required courses that each student needs to take in order to obtain their degree.

The mission statement: "The mission of the Department of Technology Support and Training is to provide exemplary knowledge, skills and attitudes for the professional success of students. To achievethis goal, we encourage and fosterteaching excellence, conduct research in businessrelated fields, and provide service to the University, to the community, and to professional organizations".

The program objectives or intended outcome are the general goals that the graduates of the TST must possess at the time of graduation. These objectives are the principles that guide the development of program courses. The objectives or the intended outcome from the TST program at IUP are listed below:

- Apply social, legal, and human issues relating to the use of technology

- Assess the need for, implement support, and evaluate information technology for the desktop environment.

- Assess the need for design, implement and evaluate technical training

- Assess the need for, design, implement, support and evaluate net working environments.

- Apply multiple methods of evaluation to determine appropriate use of technology resources for learning communication and productivity 
- Demonstrate a broad background in business and information technology

- Analyze the needs of end-users in a variety of business functions and recommend solutions to improve performance

- Determine appropriate integration of hardware devices

- Demonstrate strong interpersonal communication and team skills

- Synthesize knowledge of web page architecture design and development

- Underst and and integrate intellectual concepts related to the field of technology.

Beside the mission statement and program outcome, the T ST program requires their students to take a number of courses in order to obtain their degrees. These required courses total 120 credits and are divided among university, college and program or department requirement.

The total number of credits that are specific to the program (or T ST requirement) is 33 credits (or 11 courses). Table 1 below list the courses that are required to take by the BT ST program in order for their students to obtain the degree.

Table 1 - List of te chnology courses for the for the TS T program at IUP

\begin{tabular}{|l|l|}
\hline Course Number & Course Name \\
\hline IFMG 300 & Information Systems: Theory and Practice \\
\hline BT ST 273 & Hardware Support Solutions \\
\hline BT ST 310 & Telecommunications \\
\hline BT ST 311 & Training Methods in Business and Information Technology Support \\
\hline BT ST 383 & Microcomputer Soft ware Solutions \\
\hline BT ST 411 & Technology Support Development \\
\hline BT ST 413 & Enterprise Technology Support \\
\hline BT ST 480 & Seminar in Business Technology Support \\
\hline COSC/IFMG 352 & LAN Design and Installation \\
\hline Controlled Electives:T wo courses from the following: \\
\hline BTED 201 & Internet and Multimedia \\
\hline BT ST 401 & Web Design \\
\hline BT ST 402 & Website Development and Administration \\
\hline BT ST 493 & Internship \\
\hline COSC 110 & Problem Solving and Structured Programming \\
\hline COSC 304 & Interactive Internet Programming with Java \\
\hline
\end{tabular}

\section{The CIS/IS Programs at RMU}

The department of Computer and Information Systems in the School of Communications and Information Systems - Robert Morris University offers Bachelor of Science degrees in Computer Information Systems, Information Science, and Compet itive Intelligence. The Bachelor of Science degrees in Computer Information Systems and Information Science are both ABET-CAC accredited with one difference between them - the nat ure of the ABET-CAC required Information Systems Environment. The Computer Information Systems program requires a sequence of 6 prescribed business courses while the Information Science program requires 6 related courses that are an environment supportive of or dependent upon information systems, i.e., allied health, media management, or forensics. The curriculum otherwise consists of foundation courses, core courses, advanced core courses, and specialty courses - totaling 42 credits. As part of the three year curricular review process, model curriculum such as the IT2005, are used as a benchmark and basis of comparison. Through the use of the model curricula and the standards put forth by 
ABET-CAC, both degree programs are subject to the fulfillment of documented program objectives and program outcomes. Furthermore, Robert Morris University requires that program objectives and outcomes directly map to the University mission and strategic plan. The program outcomes (using the nomenclat ure as required by ABET-CAC) put forth for the two ABET-CAC accredited degrees are as follows:

1. An ability to design, implement and evaluate a computer-based information system, process, component, or program to meet desired business or organizational specifications

2. An ability to apply knowledge of information systems, programming and mathematics appropriate to the discipline

3. An ability to demonstrate sufficient background knowledge in Operating Systems, Networking, Dat a Communication, Dat abase T echnology, Information Systems Planning, and Project Management

4. An ability to analyze an information systems problem, define performance specifications to solve the problem and identify feasible solutions while recognizing the local and global impact of computing on individuals, organizations and society

5. An ability to function effectively on teams and to be able to communicate effectively with a range of audiences

6. An ability to use current techniques, skills, and tools necessary for information systems practices by recognizing the need for, and the ability to engage in, continuing professional development

7. An ability to understand professional, ethical, legal, security and social issues.

These program outcomes map to the ABET-CAC required outcomes (Table 2) as follows:

Table 2 Mapping ABET C riterion to RMU C IS/IS Program Outcomes

\begin{tabular}{|c|c|}
\hline ABET Criterion & $\begin{array}{l}\text { RMU Out- } \\
\text { comes }\end{array}$ \\
\hline $\begin{array}{l}\text { (a) An ability to apply knowledge of computing and mathematics appropriate to } \\
\text { the discipline; }\end{array}$ & $\begin{array}{c}1,2 \text { also 3, } \\
4\end{array}$ \\
\hline $\begin{array}{l}\text { (b) An ability to analyze a problem, and identify and define the computing re- } \\
\text { quirements appropriate to it s solution; }\end{array}$ & 4,1 \\
\hline $\begin{array}{l}\text { (c) An ability to design, implement and evaluate a computer-based system, } \\
\text { process, component, or program to meet desired needs; }\end{array}$ & $\begin{array}{l}1,2,4 \text { also } \\
3\end{array}$ \\
\hline (d) An ability to function effectively on teams to accomplish a common goal; & 5 \\
\hline $\begin{array}{l}\text { (e) An understanding of professional, ethical, legal, security, and social issues } \\
\text { and responsibilities; }\end{array}$ & 7 \\
\hline (f) An ability to communicate effectively with a range of audiences; & 5 \\
\hline $\begin{array}{l}\text { (g)An ability to analyze the local and global impact of computing on individu- } \\
\text { als, organizations and society }\end{array}$ & 4 \\
\hline $\begin{array}{l}\text { (h)Recognition of the need for, and an ability to engage in, continuing profes- } \\
\text { sional development; }\end{array}$ & 6 \\
\hline $\begin{array}{l}\text { (i)An ability to use current techniques, skills, and tools necessary for computing } \\
\text { practices. }\end{array}$ & 6 \\
\hline $\begin{array}{l}\text { (j)An understanding of processes that support the delivery and management of } \\
\text { information systems within a specific application environment. }\end{array}$ & $\mathbf{1}$ \\
\hline
\end{tabular}


This degree requires different courses that are specific to the general requirements for the university and for the school. It also requires different technology based courses. Table 3 lists the technology courses required by this program:

Table 3 Technology Courses for the C IS degree at RMU

\begin{tabular}{|l|lc|}
\hline INFS1050 & Fund Of Information Systems & 3Credits \\
\hline INFSxx10-20 & Two Courses in the Same Programming Language & 6 Credits \\
\hline INFS2210 & Operating Systems Concepts & 3 Credits \\
\hline INFS3150 & Intro Web Dev \& E-Commerce Technology & 3 Credits \\
\hline INFS3220 & Systems Analysis and Design & 3 Credits \\
\hline INFS3221 & Advanced Sys Analysis/Design & 3 Credits \\
\hline INFS3231 & Network Technology \& Mgt (N+) & 3 Credits \\
\hline INFS4240 & Database Management Systems & 3 Credits \\
\hline INFS4810 & Project Management & 15 Credits \\
\hline INFO RMATION S YSTEMS ENVIRO NMENT & 12 Credits \\
\hline \multicolumn{2}{|l}{ TRACK CO NCENTRA TIO N } & \\
\hline \multicolumn{2}{|l}{ Network Administration, Office Information Systems, Web Development } \\
\hline
\end{tabular}

\section{Comparing the Two Programs}

This section compares the content of both programs at IUP and RMU with the IT2005 content. In order to provide a better framework for comparison, the definitions, mission statements, program outcomes and courses and/or bodies of knowledge were analyzed. After the analysis was completed the authors decided that providing a comparison between the body of knowledge of IT2005 and the course listing of the two programs gives the most direct comparison among these programs and IT2005. Thus in order to complete the comparison, we performed the following steps:

First we reviewed the course title in the two programs versus the body of knowledge in IT2005. If the names matches or closely resemble each other, we reviewed the course description and knowledge units. If there is overlap among the two, we listed them as the same.

Second, if the name and title do not match, we compared the content and course description in both cases. If there is more overlap in the description we listed them again as the same courses.

Third, the courses that do not fall under any of the IT2005 body of knowledge were listed them in the outlier row.

Fourth, if there is more than one course that belongs to a specific body of knowledge, we listed them in the same body of knowledge. So often, our list contains two or more courses that belong to the same body of knowledge.

Table 4 lists the comparison of the two programs (T ST program at IUP and CIS program at RMU) with the body of knowledge in IT 2005. 
Table 4 - Comparing IT Body of Knowledge with TST and CIS Programs

\begin{tabular}{|c|c|c|}
\hline IT2005 Body of Knowledge & TST Program at IUP & CIS Program at RMU \\
\hline $\begin{array}{l}\text { ITF Information Technology } \\
\text { Fundamentals }\end{array}$ & $\begin{array}{l}\text { IFMG300 - Information Systems } \\
\text { Theory and Practice }\end{array}$ & $\begin{array}{l}\text { INFS } 1050 \text { Fundamentals of In for- } \\
\text { mation Systems }\end{array}$ \\
\hline HCI Human Computer Interaction & $\begin{array}{l}\text { BTST273 - Hardware Support } \\
\text { BTST310 - Telecommunications }\end{array}$ & $\begin{array}{l}\text { INFS } 3150 \text { Intro Web Dev \& E- } \\
\text { Commerce Technology } \\
\text { INFS } 3220 \text { System Analysis/Design }\end{array}$ \\
\hline $\begin{array}{l}\text { IAS Information Assurance and } \\
\text { Security }\end{array}$ & & $\begin{array}{l}\text { INFS } 3235 \text { Computer and Network } \\
\text { Security }\end{array}$ \\
\hline IM Information Managem ent & $\begin{array}{l}\text { BTST311 - Training Methods and } \\
\text { IT Support }\end{array}$ & $\begin{array}{l}\text { INFS } 4240 \text { Database Management } \\
\text { Systems }\end{array}$ \\
\hline $\begin{array}{l}\text { IPT Integrative Programming \& } \\
\text { Technologies }\end{array}$ & $\begin{array}{l}\text { BTST } 402-\text { Web Site Develop- } \\
\text { ment and Administration }\end{array}$ & $\begin{array}{l}\text { INFS } 4850 \text { Web Development and } \\
\text { eCommerce II } \\
\text { INFS } 3221 \text { Advanced Systems } \\
\text { Analysis and Design }\end{array}$ \\
\hline NET Networking & $\begin{array}{l}\text { COSC352 - LAN Design and In- } \\
\text { stallation } \\
\text { BTST310 - Telecommunications }\end{array}$ & $\begin{array}{l}\text { INFS } 3230 \text { Network Technology \& } \\
\text { Mgt (N+) } \\
\text { INFS } 3230 \text { Networks and Data } \\
\text { Communication }\end{array}$ \\
\hline PF Programming Fundamentals & $\begin{array}{l}\text { COSC110 - Problem Solving and } \\
\text { Structured Programming }\end{array}$ & INFS 2120 VB.NET \\
\hline PT Platform Technologies & $\begin{array}{l}\text { BTST } 383 \text { - Microcomputer Soft- } \\
\text { ware Solution }\end{array}$ & \\
\hline $\begin{array}{l}\text { SA Systems Administration and } \\
\text { Maintenance }\end{array}$ & & $\begin{array}{l}\text { INFS } 2210 \text { Operating Systems Con- } \\
\text { cepts } \\
\text { INFS } 2211 \text { Microcomputer Tech- } \\
\text { nology }(\mathrm{A}+)\end{array}$ \\
\hline $\begin{array}{l}\text { SIA System Integration \& Archi- } \\
\text { tecture }\end{array}$ & $\begin{array}{l}\text { BTST } 480 \text { - Seminar in Technol- } \\
\text { ogy Support }\end{array}$ & \\
\hline SP Social and Professional Issues & & $\begin{array}{l}\text { INFS } 4170 \text { Global, Econo mic, So- } \\
\text { cial, and Ethical Issues in Comput- } \\
\text { ing }\end{array}$ \\
\hline $\begin{array}{l}\text { WS Web Systems and Technolo- } \\
\text { gies }\end{array}$ & BTST401 - Web Design & $\begin{array}{l}\text { INFS } 3150 \text { Intro Web Dev \& E- } \\
\text { Commerce Technology } \\
\text { INFS } 4150 \text { Advanced Web Dev \& } \\
\text { E-Commerce Technology }\end{array}$ \\
\hline $\begin{array}{l}\text { Outlier (Courses do not fall un- } \\
\text { der any of the body of knowl- } \\
\text { edge areas) }\end{array}$ & $\begin{array}{l}\text { BTED201 - Internet and Multi- } \\
\text { media } \\
\text { BTST411 - Technology Support } \\
\text { Development } \\
\text { BTST413 - Enterprise Technology } \\
\text { Support }\end{array}$ & $\begin{array}{l}\text { INFS } 4810 \text { Project Management } \\
\text { INFS } 3450 \text { Quantitative Analysis } \\
\text { for In formation Systems Profes - } \\
\text { sionals }\end{array}$ \\
\hline
\end{tabular}




\section{Conclusion and Future Plan}

Table 4 in the previous section provides a comparison between the TST and CIS programs with the IT2005 body of knowledge. After further reviewing the table above, we made the following observation/conclusion regarding the content of the programs as compared to the IT2005 body of knowledge.

First, there are certain "body of knowledge" areas listed in IT2005 that do not have comparable courses in the programs. These are missing courses from the two programs. In the case of the TST program, the missing courses consist of IAS Information Assurance and Security, SA Systems Administration and Maintenance, and SP Social and Professional Issues. For RMU the missing course coverage involves two courses: PT Platform Technologies and SIA Systems Integration and Architecture.

Second, the course names of the programs vary significantly from their counterpart of the name of body of knowledge. Course name plays an important role in giving an understanding of their content. Thus, if both the T ST and RMU CIS/IS programs want to align with IT2005 body of knowledge, revision of course names become important.

Third the naming of both programs differs from the name listed in IT2005 (Information Technology). Giving an appropriate name to the courses and programs is import ant in learning the content of the program and courses and helps identify the alignment of the program to certain field of technology. In the case of the T ST program, the name Technology Support and Training does not give a close meaning of alignment to the name "Information Technology" as is the case with the Information Sciences Program at RMU, thus a change of name of these programs is essential prior to taking any step of program or course revision.

Despite the review that we conducted and the comparison we provided here in this paper, we feel that the study is still short on detail about course description and units each course offers. The IT 2005 list a number of units for its' discipline as well as a suggested number of hours for each unit. Thus in order to provide a more meaningful comparison of the content that each program

offers, a more detailed study comparing these course contents is essential. Thus the authors of this paper intend a follow-up study were we are going to take a course by course content from both programs and compare them with the units and hours listed in the IT 2005 list of body knowledge area units.

\section{References}

Ali, A., Kohun, F, \& Wood, D. (2007). Comparing two programs with computing curriculum 2005 knowledge area. Issues in Information Systems. VIII, 1, 91-96.

Computing curricula 2005 the overview report (2005). Retrieved October 2, 2006 from ACM Digital Library http://www.acm.org/dl

Computing Curricula Information Technology Volume (2005). Retrieved March 4, 2007 from ACM Digital Library http://www.sigite.org/

Dark, M. J., Ekstrom J. J., \& Lunt B. B. (2006). Integrating information assurance and security into IT education: A look at the model curriculum and emerging practice. Journal of Information Technology Education, 5, 389-403. Retrieved from http://iite.org/documents/Vol5/v5p389-403Dark127.pdf

Hart, M. (2006). The information technology model curriculum. Journal of Information Technology Education, 5, 337-342. Retrieved from http://jite.org/documents/Vol5/v5p337-342Hart.pdf

Reynolds, C. W. (2006). Engineering the information technology curriculum with pervasive themes. Proceedings of the 7th Conference on Information Technology Education, Minneapolis, Minnesota, USA. Retrieved March 2, 2007 from ACM Digital Library http://www.acm.org/dl 


\section{Biographies}

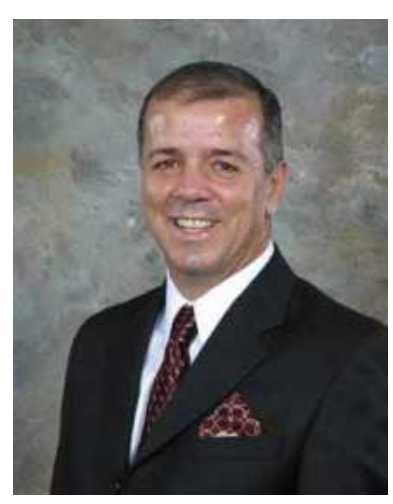

Azad Ali, D.Sc., Associate Professor of Technology Support and Training at Eberly College of Business - Indiana University of Pennsylvania has 25 years of combined experience in areas of financial and information systems. He holds a bachelor degree in Business Administration form the University of Baghdad, an M.B. A. from Indiana University of Pennsylvania, an M.P.A. from the University of Pittsburgh, and a Doctorate of Science in Communications and Information Systems form Robert Morris University. Dr. Ali's research interests include object oriented languages, web design tools, doctoral studies and curriculum design. His community service and academic expertise gets him in the news on Pittsburgh television and in the newspapers.

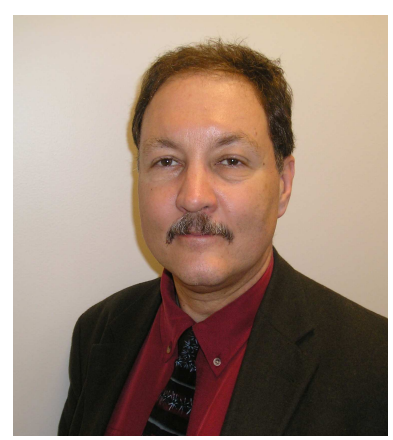

Frede rick G. Kohun, Ph.D., Associate Dean and Professor in the School of Communications and Information Systems at Robert Morris University in Pittsburgh, has more that 30 years experience as a professor and administrat or in the information systems field. He holds a bachelor degree in economics from Georget own University, graduate degrees in economics and information science, from the University of Pittsburgh, and a Ph.D. in applied history in technology from Carnegie Mellon University. He had a leadership role in the design and implementation of eight technology based academic programs at the undergraduate and graduate level including a doctoral program. Most recently, he was involved in the first round of ABET-CAC information systems accreditation. 